SPRING 2008

Volume 60, Number 2

EVE CÉLIA MORISI

\title{
The OuLiPoe, or Constraint and (Contre-) Performance: "The Philosophy of Composition" and the Oulipian Manifestos
}

\author{
"I kept steadily in view the design of rendering \\ the work universally appreciable" \\ -Edgar Allan Poe, "The Philosophy of Composition" \\ "Maintenant, voyons la coulisse, l'atelier, le \\ laboratoire, le mécanisme intérieur [. . .]" \\ (Now, let us take a look behind the scenes, \\ see the workshop, the laboratory, the interior \\ mechanism ...) \\ —Charles Baudelaire, "La Gènèse d'un poème"
}

\begin{abstract}
7 HE WORKS OF EDGAR ALLAN POE (1809-1849), one of the masters of American fiction and poetry, and the writings of the Ouvroir de Litterature Potentielle (Workshop of Potential Literature or OuLiPo), a group of writers and mathematicians founded in 1960 by Raymond Queneau (1903-1976) and François Le Lionnais (1901-1984) in order "to give tools to create literature by other means," 1 form an improbable whole. The comparison between a single author and an association may seem odd, and Poe and the OuLiPo are separated

I am deeply indebted to my friend Eliza Zingesser for her meticulous and generous reading of this essay. Thanks also to Mr. Kevin Miserocchi, Executive Director of the Tee and Charles Addams Foundation, for kindly allowing me to reproduce Charles Addams's irresistible cartoon.

${ }^{1}$ This is how Paul Fournel, the OuLiPo's current president, summarized the purpose of the group in a seminar, "Constraint in Modern European Fiction and Poetry," given 11 Oct. 2005 at Princeton University.
\end{abstract}


by chronological, geographical, and cultural differences. In addition, they seem to feature deeply dissimilar personalities, productions, and approaches to literature: while Poe's writings quite consistently revolve around the most heart-felt, solemn, or disturbing situations, feelings, and experiences, the OuLiPo is known for its sense of décalage that disqualifies earnestness with charming insolence. And yet, from these two literary subjectivities (let us here consider the OuLiPo as a homogeneous rather than eclectic ensemble) emerges a common theoretical concern: literary constraint and its status in literary production. This connection is one that has been overlooked by criticism. Although scholars have been interested in associating the works of Poe with the Oulipian writer Georges Perec (1936-1982), they have not explored the parallels that link the theoretical constraint-centered writings of the American author to the literary theories of the OuLiPo. This essay will examine these parallels in order better to understand the spirit in which literature is approached and (re)claimed by these writers. For the purposes of this brief article, I will focus on three key theoretical texts: for Poe, "The Philosophy of Composition," published in Graham's Magazine in April 1846, and, for the OuLiPo, "La LiPo (Le premier Manifeste)" and "Le second Manifeste," written by OuLiPo founding co-president François Le Lionnais in 1961 and 1973 respectively. In addition to their agenda-like quality, these three texts, I argue, converge transhistorically and transnationally in their common interest in a constraint that articulates itself around the notion of (contre-) performance.

\section{Synthesis of "The Philosophy of Composition" and Constraint:}

\section{A (Narrative) Discourse, a Truth?}

In "The Philosophy of Composition" (1846), "the living example of how much, to [Poe's] way of thinking, the artist should do" (Jannacone 3), Edgar Allan Poe highlights a cardinal theme that he would take up in subsequent theoretical essays: the mechanics of poetry. Indeed, the 1846 text sets a clear and rigorous analytical tone that is reproduced in "The Rationale of Verse," published in 1848 in the Southern Literary Messenger, and "The Poetic Principle," which appeared posthumously in Sartain's Union Magazine in 1850 and places particular emphasis on the autonomy of the poem "for the poem's sake" (Poe 76).

The specificity of "The Philosophy of Composition," on the other hand, lies in its status-and genesis—as a text that it is inseparable from and constitutes "the companion piece to Poe's 'The Raven'” (Richards 53). By means of a reconstitution of the work of "pre-writing," which I summarize in the table below, Poe claims to unveil the retrograde composition process that governs his famous poem: "It is my design to render it manifest that no one point in its composition is referable either to accident or intuition-that the work proceeded, step by step, to its completion with the precision and rigid consequence of a mathematical problem" (Poe 14-15). ${ }^{2}$

\footnotetext{
${ }^{2}$ This tabular format does not purport to be exclusive or exhaustive. Rather, it aims at underlining the rigorous (quasi-systematic and causal) quality of Poe's description of the composition process. The author's insistence on the scientific nature of poetry making is worthy of our attention -beyond the fact that the "mathematical" nature that he ascribes to his work may at first seem essentially metaphorical.
} 


\begin{tabular}{|c|c|}
\hline $\begin{array}{l}\text { CONSTRAINING } \\
\text { CONSIDERATIONS } \\
\text { in chronological order }\end{array}$ & $\begin{array}{l}\text { CHOICE and TEXTUAL } \\
\text { MANIFESTATIONS of the constraint }\end{array}$ \\
\hline $\begin{array}{l}1 \text { - LENGTH } \\
\text { "The initial consideration was } \\
\text { that of extent" }\end{array}$ & $\Rightarrow>$ "a length of about one hundred lines" \\
\hline $\begin{array}{l}\text { 2- EFFECT } \\
\text { "the choice of an impression, } \\
\text { or effect, to be conveyed" }\end{array}$ & $\begin{array}{l}\Rightarrow \text { "Beauty is the sole legitimate province } \\
\text { of the poem" }\end{array}$ \\
\hline $\begin{array}{l}\text { 3-TONE } \\
\text { "my next question referred to } \\
\text { the tone of [Beauty's] highest } \\
\text { manifestation" }\end{array}$ & $\begin{array}{l}\Rightarrow>\text { "all experience has shown that this tone } \\
\text { is one of sadness" }\end{array}$ \\
\hline $\begin{array}{l}4 \text { - (TEXTUAL) PIVOT } \\
\text { "some pivot upon which the } \\
\text { whole structure might turn" }\end{array}$ & $\begin{array}{l}=>\text { "no one had been so universally } \\
\text { employed as that of the refrain" }\end{array}$ \\
\hline $\begin{array}{l}\text { 5- NATURE OF REFRAIN } \\
\text { "I next besought me of the } \\
\text { nature of my refrain" }\end{array}$ & $=>$ "a single word as the best refrain" \\
\hline $\begin{array}{l}\text { 5.1 - Application of refrain } \\
\text { "I resolved to diversify, and } \\
\text { so heighten, the effect, by } \\
\text { adhering, in general, to the } \\
\text { monotone of sound, while } \\
\text { I continually varied that of } \\
\text { thought" }\end{array}$ & $\begin{array}{l}\Rightarrow>\text { "I determined to produce continuously } \\
\text { novel effects, by the variation of the } \\
\text { application of the refrain-the refrain itself } \\
\text { remaining, for the most part, unvaried" }\end{array}$ \\
\hline $\begin{array}{l}\text { 5.2 - Sound of word-refrain } \\
\text { "The question now arose as to } \\
\text { the character of the word" }\end{array}$ & $\begin{array}{l}=>\text { "the long } o \text { as the most sonorous vowel, } \\
\text { in connection with } r \text { as the most produc- } \\
\text { ible consonant" }\end{array}$ \\
\hline $\begin{array}{l}\text { 5.3 - Selection of word-refrain } \\
\text { "it became necessary to select } \\
\text { a word embodying this sound" }\end{array}$ & $\begin{array}{l}=>\text { "it would have been absolutely impos- } \\
\text { sible to overlook the word 'Nevermore"" }\end{array}$ \\
\hline \multicolumn{2}{|c|}{$\begin{array}{l}\text { 5.4 - Pretext/speaker for utterance of word-refrain } \\
\text { (and conception of "The Raven" fulfilled) } \\
\text { "I had now gone so far as the conception of a Raven-the bird of ill omen } \\
\text {-monotonously repeating the one word, 'Nevermore,' at the conclusion } \\
\text { of each stanza" }\end{array}$} \\
\hline $\begin{array}{l}\text { 6- TOPIC } \\
\text { "I asked myself-'Of all melan- } \\
\text { choly topics, what, according } \\
\text { to the universal understand- } \\
\text { ing of mankind, is the most } \\
\text { melancholy?"” }\end{array}$ & => "Death-was the obvious reply" \\
\hline
\end{tabular}




\begin{tabular}{|c|c|}
\hline $\begin{array}{l}\text { 6.1 - Context for optimization } \\
\text { of topic } \\
\text { “'and when,' I said, 'is this } \\
\text { most melancholy of topics } \\
\text { most poetical?'” }\end{array}$ & $\begin{array}{l}\Rightarrow>\text { "the death, then, of a beautiful woman } \\
\text { is, unquestionably the most poetical topic } \\
\text { in the world" }\end{array}$ \\
\hline \multicolumn{2}{|c|}{$\begin{array}{l}\text { 6.2 - Speaker for optimization of topic } \\
\text { "and equally is it beyond doubt that the lips best suited for such topic are } \\
\text { those of a bereaved lover" }\end{array}$} \\
\hline $\begin{array}{l}7 \text { - COMBINATION OF TOPIC } \\
\text { AND WORD-REFRAIN } \\
\text { "I had now to combine the two } \\
\text { ideas, of a lover lamenting his } \\
\text { deceased mistress and a Raven } \\
\text { continuously repeating the } \\
\text { word 'Nevermore'" }\end{array}$ & $\begin{array}{l}\Rightarrow>\text { "the only intelligible word of such com- } \\
\text { bination is that of imagining the Raven } \\
\text { employing the word in answer to the } \\
\text { queries of the lover" }\end{array}$ \\
\hline $\begin{array}{l}8 \text { - EVOLUTION OF POEM'S } \\
\text { TONE AND ATMOSPHERE } \\
\text { "bearing in mind my design } \\
\text { of varying at every turn, the } \\
\text { application of the word } \\
\text { repeated" }\end{array}$ & $\begin{array}{l}\Rightarrow>\text { "I saw at once the opportunity afforded } \\
\text { for the effect on which I had been depend- } \\
\text { ing--that is to say, the effect of the variation } \\
\text { of application. I saw that I could make the } \\
\text { first query propounded by the lover-the } \\
\text { first query to which the Raven should reply } \\
\text { 'Nevermore'-that I could make this first } \\
\text { query a commonplace one-the second } \\
\text { less so-the third still less, and so on" }\end{array}$ \\
\hline $\begin{array}{l}9 \text { - CLIMAX } \\
\text { "I first established in mind the } \\
\text { climax or concluding query" }\end{array}$ & $\begin{array}{l}=>\text { "the query to which 'Nevermore' } \\
\text { should be in the last place an answer" }\end{array}$ \\
\hline $\begin{array}{l}\text { 10-COMPOSITION OF } \\
\text { LAST STANZA } \\
\text { "Here then the poem may be } \\
\text { said to have its beginning-at } \\
\text { the end, where all works of art } \\
\text { should begin, for it was here, } \\
\text { at this point of my preconsid- } \\
\text { erations, that I first put pen to } \\
\text { paper, in the composition of } \\
\text { the stanza" }\end{array}$ & $\begin{array}{l}\Rightarrow>\text { "'Prophet!' said I, 'thing of evil! prophet } \\
\text { still if bird or devil! } \\
\text { By that heaven that bends above us-by } \\
\text { that God we both adore, } \\
\text { Tell this soul with sorrow laden, if within } \\
\text { the distant Aidenn, } \\
\text { I shall clasp a sainted maiden whom the } \\
\text { angels name Lenore- } \\
\text { Clasp a rare and radiant maiden whom } \\
\text { the angels name Lenore.' } \\
\text { Quoth the Raven, 'Nevermore." }\end{array}$ \\
\hline
\end{tabular}

Brief overview of Poe's "Philosophy of Composition" (before the poet "put[s] pen to paper" )

There are a few striking idiosyncrasies in Poe's account. First and foremost, it seems to claim a sense of "universality" (17) both in the logical and quasi-systematic development of the composition process that it presents (as the table shows) and in its ambition for absolute "effect[iveness]" (Poe 13). This propensity for 
expansion and diffusion reveals a thirst for both quantitative and qualitative success, that is, a thirst for a maximum productivity that at once aims at seducing all members of its audience ("the popular and the critical taste," Poe 15) and at controlling-and enhancing-the composition's power. Poe's text consequently postulates and pivots upon the reader as a determining figure, the common denominator that conditions the widely favorable reception of the poem and the intense reaction that it purports to trigger. Furthermore, although the reader is obviously a consideration for every publication-oriented writer in one way or another, Poe intensifies that consideration in a text that, in addition to evoking the importance of the reader for the poem, is itself destined for this very reader.

Indeed, if "The Philosophy of Composition" ostensibly narrates the story of how the American poet wrote "The Raven," it first presents itself as a discourse that frames this narrative. Poe's use of the first person as a referential pronoun, his vivid (if not polemical) tone, and his assertiveness in sentence modalization testify to this discursive, oratorical quality. But the text's embedded structure (as a narrative inserted within a discourse) is not manifest at the formal level only. For the account's content seems constantly to oscillate between reporting the various stages of the poem's composition in a factual narrative mode and imposing on its readers the claim that these stages follow one another "with the precision and rigid consequence of a mathematical problem" (15) by means of a dubious "reconstruction" (14).

The aporia that ensues between the supposed self-imposition of the composition's steps and their forced exposition is visible in two antagonistic predicates used by Poe: "Perceiving the opportunity thus afforded me-or, more strictly, thus forced upon me in the progress of the construction" (Poe 19; my emphasis). If such rephrasing seeks to hyperbolize the imperatives to which the author may be subject during the composition process, it simultaneously betrays the existence of chance and thereby refutes the idea that causality and logic exclusively determine his writing. There is, however, a greater aporia in the split between Poe's introduction to and the actual narrative of the composition of "The Raven." In the first section of the text, one is told that "every plot, worth the name, must be elaborated to its dénouement before anything is attempted with the pen" and that, as a result of this process, "most writers" find that their "fully matured fancies [must be] discarded in despair as unmanageable" and experience "painful erasures and interpolations" $(13,14)$ in the text's discursive frame. Yet these "erasures and interpolations" also lead to the replacement of the writer's difficulties and struggles by an unrealistic sense of "facility" (18), perfection, and systematization.

Owing to a double textual inconsistency-typological and methodological—one is thus led to question whether Poe's composition process is as scientific as he claims it to be. Furthermore, additional questions arise. Is it possible that the substantial number of constraints (structural, thematic, and phonic) to which the poet refers could have been mastered without any overlap, following an ordered and impeccably linear enchaînement? Indeed, various punctual complexifications in the composition process suggest that different phases cannot be truly dissociated from one another chronologically. The above table bears witness to this as it gathers together, for instance, the necessarily interconnected "sub-steps" that 
led to determining the "nature of the refrain" or the "topic." Hence a more fundamental interrogation with which any reader of "The Philosophy of Composition" is eventually faced: doesn't this account, despite its extraordinarily Cartesian rhetoric, reveal here and there the ultimate untranslatability of all the psychological operations that are at stake in embedding the composition process into an all-encompassing and mathematically oriented formula?

Besides, and more pragmatically, critics have argued that Poe's listing of the constraints that underlie the composition of "The Raven" is inauthentic precisely because it purports to demonstrate the writer's absolute mastery of both form and content without leaving any room for chance. From this point of view, Poe's account reveals manipulation rather than "preconsiderations" (Poe 20):

Though it purports to be an account of how Poe went about the writing of his poem "The Raven," and though he might be expected to know more about his procedures than any one else, the general tendency has been to feel that he is making the genesis of the poem look much more deliberate than could have possibly been the case, and to assume that he did so either for purposes of showmanship or to compensate for his own personal shortcomings by representing himself as a paragon of rational control. (Burke 25)

Charles Addams makes the same point in a series of four cartoons that depict Poe in the painful process of making the supposedly tactical choices on which the success of "The Raven" would later depend (see one of them below).

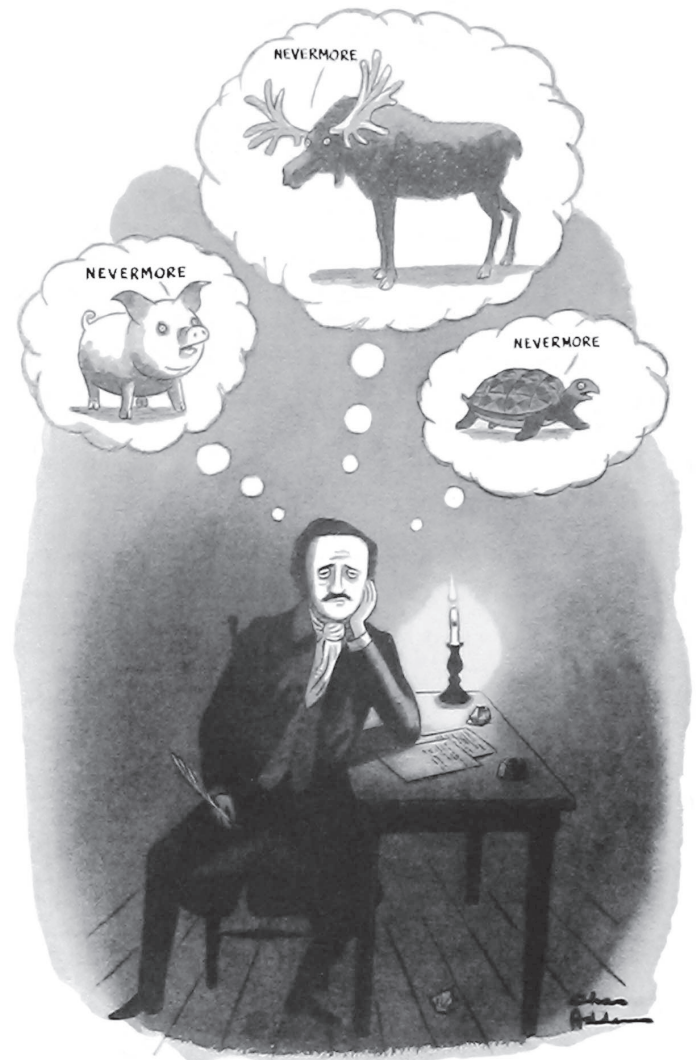

Charles Addams, "Nevermore," cartoon, New Yorker 29 Oct. 1973: 33.

(C) Tee and Charles Addams Foundation 
In addition, if "The Philosophy of Composition" appears to be problematic in its mechanics and/or its ethics, it is even more so in the way it represents constraint. This representation (in the sense of a mere rendering and of a presentation that takes place after another-the actual composition), which federates the text, calls for a reevaluation: that of the concept of literary constraint itself. In Poe's text, literary constraint loses its intrinsic qualities and function. The constraints here at stake no longer come first, prior to the writing; their formulation follows the poem's composition instead of preceding it, and therefore cannot be proved to have presided over it. Even if one chooses to trust in Poe's good faith - that is, in his having actually abided by the thematic, structural, and phonic constraints he describes as satisfyingly productive before "put[ting] pen to paper" (Poe 20) — the a posteriori nature of "The Philosophy of Composition" symbolically destabilizes the notion of literary constraint he champions so emphatically.

Consequently, the concern with productivity that is inherent in literary constraint and that is repeatedly underlined by the author paradoxically ends up being overturned, at least in part. Although constraint is generally understood as generating literature from within, Poe here clearly designs it for externalization rather than internalization. The motivation behind such a capsizing of constraint can be read as promotional, didactic, prescriptive, ludic - or all of these at once. ${ }^{3}$ Regardless, Poe's account of literary constraint does signal his underlying attempt to redefine literary production (and the production of poetry in particular) as an object of reason rather than passion-an object whose control Poe actively claimed and sought to exhibit in "The Philosophy of Composition," however truthful or untruthful its account of the composition of "The Raven" may be.

\section{Synthesis of the Oulipian Manifestos: A Productive Recreation}

As a potentially erroneous, reworked, or fantasized account of the composition of "The Raven" that somehow reverses constraint, "The Philosophy of Composition" does not seem to call for a comparison with an Oulipian enterprise that meticulously defines its literary constraints before applying them with rigor. However, an examination of the two manifestos that marked the advent of the OuLiPo will complicate this assumption.

Both "La LiPo (Le premier Manifeste)" and "Le second Manifeste" show striking similarities with Poe's "Philosophy." The three texts revolve around the process of literary fabrication - which for the OuLiPo may orient itself towards either the re(dis) covery of past constraints (also known as "anoulipisme"), "qui dépassent souvent ce que les auteurs avaient soupçonné" (Le Lionnais, "La LiPo" 21-22; "which often exceed what the authors had expected"), or the invention of new ones ("synthoulipisme"). ${ }^{4}$ This double design of identifying and generating constraint echoes the qualitative and quantitative concerns that Poe expresses in his

\footnotetext{
${ }^{3}$ I will examine the implication of these motivations, i.e. a sense of egocentricity, in the third section of this essay.

${ }^{4}$ Translations are mine unless otherwise indicated.
} 
text. Moreover, like Poe's, Le Lionnais's writing betrays a constant hesitation between fact and interpretation, between necessity and proclamation, between what I termed the "self-imposition" and the "exposition" of constraint. On the one hand, the author insists that "ce n'est pas au hasard qu[e l'écrivain] adopte une forme au lieu d'une autre" ("Le second Manifeste" 25; "it is not at random that the writer adopts one form instead of another") and that constraint improves "l'efficacité [...] des structures littéraires" (24). On the other hand, he indulges in a somewhat convoluted discourse about these constraints. And let us note that, here again, two textual typologies are intertwined: Le Lionnais's declarative discourse is interspersed with narrative considerations, whether historical or anecdotal. He somehow revisits, through brief evocations, the history of "les adversaires de l'invention du langage"- "sensibles qu'ils étaient à la beauté des cris, à l'expression des soupirs" ("La LiPo" 20; "sensitive as they were to the beauty of the cries, to the expression of the sighs") —or the "ancienne querelle des Anciens et des Modernes" ("Le second Manifeste" 26), for instance. Or else he recounts his own past "flân[erie] dans les allées du jardin des Plantes" ("Le second Manifeste" 27; "stroll down the paths of the jardin des Plantes").

At their core, the two Oulipian manifestos are also reminiscent of Poe's account in that they take to its extreme his concerns with rationality and productivity: "Ce que certains écrivains ont introduit dans leur manière [...] l'Ouvroir de Littérature Potentielle (OuLiPo) entend le faire systématiquement et scientifiquement" (Le Lionnais, "La LiPo" 21; "What some writers introduced in their manner [...] the Ouvroir de Littérature Potentielle intends to do systematically and scientifically"). The Oulipian goal is exhaustion, as this statement indicates, and Le Lionnais, fascinated with potentiality, rejoices in the fact that "les mathématiques contemporaines [...] proposent mille directions d'exploration" ("La LiPo" 21; "contemporary mathematics [...] offers a thousand directions for exploration") and that there exists "toute une gamme de structures plus ou moins contraignantes" ("Le second Manifeste" 25; "a whole gamut of more or less constraining structures").

If these claims for the exploration and application of constraint emerge as more "realistic" than Poe's insofar as one cannot stigmatize them for their a posteriori nature, they still convey a sense of subversion that parallels that of "The Philosophy of Composition" (what I termed the text's "capsizing" of constraint). For humor runs so rampant in Le Lionnais's texts that their scientific and procreative design systematically falls prey to deflation. The "C.Q.F.D." mentioned at the end of "La LiPo" exemplifies the recurrent self-deriding gesture with which Le Lionnais paradoxically seems to take back whatever serious Oulipian projects, ideas, or illustrations thereof he presents in the manifestos. This occurrence of "C.Q.F.D.," i.e. "Ce qu'il fallait démontrer" (quod erat demonstrandum) notably follows an ironic and sophistic argumentation that aims at asserting the "sérieu[x]" of potential literature:

Un mot, enfin, à l'intention des personnes particulièrement graves qui condamnent sans examen et sans appel toute oeuvre où se manifeste quelque propension à la plaisanterie.

Lorsqu'ils sont le fait de poètes, divertissements, farces et supercheries appartiennent encore à la poésie. La littérature potentielle reste donc la chose la plus sérieuse du monde (Le Lionnais, "Le second Manifeste" 22) 
A word, lastly, to the attention of the particularly grave people who condemn without examination and without appeal any work in which some propensity for joking manifests itself. When they are the product of poets, amusement, farce and hoax still belong to poetry. Potential literature therefore remains the most serious thing in the world.

As it multiplies such witticisms, the exposé of the Ouvroir's agenda therefore appears to morph into a "farc $[\mathrm{e}]$ " or fantaisie where free associations as well as some scathing second degré prevail. ${ }^{5}$

The Oulipian manifestos, in short, subvert literary constraint in that they are made to serve an active desacralization of literature (and of the arts in general). ${ }^{6}$ With them, Bach becomes "B.A.C.H.," an instance of how productive acrostics can be in music, and the famous first line of John Keats's "Endymion"- "A thing of beauty is a joy forever"-finds its supposed translation (its phonetic retranscription, in fact) in the harebrained French aphorism "Un singe de beauté est un jouet pour l'hiver" ("A monkey of beauty is a toy for the winter") (Le Lionnais, "Le second Manifeste" 27). More generally, the serious question that Le Lionnais does pose about constraint in "La LiPo" and "Le second Manifeste," that of "l'efficacité et la viabilité des structures littéraires [...] artificielles" ("Le second Manifeste" 24; "the efficiency and viability of artificial literary structures"), is subsumed by the texts' spirit of entertainment. A joyful celebration of language and the paradoxical mastery of propensity to slippage convey this spirit:

Célébrer le langage, c'est se délecter de sa polymorphie, de son aptitude à l'équivoque, au glissement, au brouillage, de son art tout ironique à mener là où on ne savait pas que l'on irait. C'est aussi se confronter à son pouvoir de structuration, de tressage et de construction, à la force de cet outil qui mène là où on veut qu'on aille. Le talent de l'Oulipo (ce fut aussi celui de Freud) a été de tirer profit de cette contradiction fondamentale du langage. (Burgelin 36)

To celebrate language is to delight in its polymorphism, its aptitude for equivocation, slippage, blurring, in its rather ironic art of leading where one did not know one would go. It is also to confront its power of structuration, of weaving, and of constitution, to confront the force of this tool that leads where one wants to go. The talent of the Oulipo (it was also that of Freud) was to make the most of this fundamental contradiction of language.

One finds in other Oulipian writings that define the Ouvroir's nature and mission the same linguistic excitement. Consider, for example, the following introduction to the group, written by Marcel Benabou and Jacques Roubaud, elected to the OuLiPo in 1969 and 1966, respectively:

OULIPO? Qu'est ceci? Qu'est cela? Qu'est-ce que OU? Qu'est-ce que LI? Qu'est-ce que PO?

OU c'est OUVROIR, un atelier. Pour fabriquer quoi? De la LI.

LI c'est la littérature, ce qu'on lit et ce qu'on rature. Quelle sorte de LI? La LIPO.

PO signifie potentiel. De la littérature en quantité illimitée, potentiellement productible jusqu'à la fin des temps, en quantités énormes, infinies pour toutes fins pratiques.

QUI? Autrement dit qui est responsable de cette entreprise insensée?

Raymond Queneau, dit RQ, un des pères fondateurs, et François Le Lionnais, dit FLL,

co-père et compère fondateur, et premier président du groupe, son Fraisident-Pondateur.

Que font les OULIPIENS, les membres de l'OULIPO (Calvino, Perec, Marcel Duchamp, et autres, mathématiciens et littérateurs, littérateurs-mathématiciens, et mathématiciens-littérateurs)?

${ }^{5}$ This is not to say that interjections of humor compromise the formalism and rigor of the Oulipian work, but rather that this mathematical enterprise is inseparable from a frantically jocular framework.

${ }^{6}$ This desacralization is summarized by a panoramic view of literature that Le Lionnais encapsulates in the following formula: "Ceux que l'on appelle les Anciens sont, bien souvent, les descendants sclérosés de ceux qui, en leur temps, furent des Modernes" ("La LiPo" 20; "Those whom we call the Ancients are, quite often, the sclerotic descendants of those whom, in their days, were the Moderns"). 
Ils travaillent.

Certes, mais à QUOI? A faire avancer la LIPO.

Certes, mais COMMENT?

En inventant des contraintes. Des contraintes nouvelles et anciennes, difficiles et moins diiffficiles et trop diiffiiciiiles. La Littérature Oulipienne est une LITTERATURE SOUS CONTRAINTES. Et un AUTEUR oulipien, c'est quoi? C'est "un rat qui construit lui-même le labyrinthe dont il se propose de sortir".

Un labyrinthe de quoi? De mots, de sons, de phrases, de paragraphes, de chapitres, de livres, de bibliothèques, de prose, de poésie, et tout ça . . .

(Benabou Roubaud)

OULIPO? What is this? What is that? What is OU? What is LI? What is PO?

OU is for OUVROIR, an atelier. To make what? LI.

LI is for literature, what you read, what you cross out. What kind of LI? LIPO.

PO stands for potential. Literature in unlimited quantity, potentially producible until the end of time, in enormous, infinite quantities for all practical purposes.

WHO? In other words, who is responsible for this nonsensical enterprise? Raymond Queneau, aka RQ, one of the founding fathers, and François Le Lionnais, aka FLL, co-founding father and comrade, and first president of the group, its Pounding Fresident.

What do the OULIPIENS, the members of the OULIPO (Calvino, Perec, Marcel Duchamp, and others, mathematicians and men of letters, men-of-letters-mathematicians, and mathematiciansmen-of-letters) do? They work.

Indeed, but what for? For the advancement of LIPO.

Indeed, but HOW?

By inventing constraints. New and old constraints, difficult and less diiffficult and too diiffiicuuult. Oulipian Literature is a LITERATURE UNDER CONSTRAINTS.

And what is an Oulipian AUTHOR? It is "a rat that itself constructs the labyrinth that it sets itself the task of getting out of."

A labyrinth of what? Of words, sounds, sentences, paragraphs, chapters, books, libraries, prose, poetry, and all that...

This text confirms what we have seen emerge from the first and second manifestos: a will to reactivate or create constraint that (self) mockery tempers. Clearly, such playfulness does not apply to "The Philosophy of Composition." Yet it does allow the OuLiPo to operate along Poe's lines: it conditions an ostentatious-if not an exhibitionistic-re-appropriation of constraint. In other words, if, as we have seen, Poe redefines and reclaims the concept of constraint in his account insofar as he actually uses it as a pretext for exhibiting his control of literature, Le Lionnais proceeds similarly. He makes the notion of constraint his own both by proposing to take it to a new (a greater) level of production- "L'OuLiPo a la conviction, très forte, qu'on pourrait en envisager un bien plus grand nombre" ("en" refers to "structures . . contraignantes") ("Le second Manifeste" 25; "The OuLiPo has the very strong conviction that one could envisage a much greater number [of constraining structures]")—and by defusing its seriousness. This resemblance between the Poe and Oulipian enterprises is all the more notable as their common appropriative gesture inscribes itself in texts whose titles and genre-whether "The Philosophy" or the "Manifeste" ( literally meaning "struck by hand")-indicate that their authors embrace consciousness.

\section{From Constraint to the Poetics of Performance}

Poe and the members of the OuLiPo, who together make up what may be termed 
the "OuLiPoe"- a merger of names justified by a merger of authorial enterprises —do share, despite all appearances, an essential feature: they alertly "personalize" the concept of constraint and, by means of this re-appropriation, redefine it. This constraint-centered likeness, I argue, brings a common modus operandi to light: "The Philosophy of Composition" and the two Oulipian manifestos both revolve around the production of literature and the staging of this production. This dyad can be summed up by the polysemous French term performance.

Performance denotes, among other things, the notion of output and achievement, and of dramatic representation or interpretation. The OuLiPoe is characterized, all in all, by an obsessive inclination for performance: literary production must be mastered ${ }^{7}$-and increased tenfold-and the discourse that advocates this mastery and increase is, as we shall see, theatricalized. The motivation behind such overdetermination seems first to relate to a rejection of spontaneity, that is, to the avoidance of a potential disorder. For Poe, "a species of fine frenzy-an ecstatic intuition" (14) is the explicit enemy. Such hostility is comprehensible if one considers Poe's writing within its literary context: a time that both revived and celebrated the power of inspiration, that transcendental power of the muses over the writer already invoked by the poets of Antiquity and the Renaissance. To resist this myth, Poe "decomposes the poem into its elements in order to expose the fiction of lyric voice" (Richards 53). Similarly, the OuLiPo condemns the fallaciousness of inspiration-here parenthetically—to highlight the significance of lexical, synctactic, structural, or formal constraints:

Toute oeuvre littéraire se construit à partir d'une inspiration (c'est du moins ce que son auteur laisse entendre) qui est tenue à s'accommoder tant bien que mal d'une série de contraintes qui rentrent les unes dans les autres comme des poupées russes. Contraintes du vocabulaire ou de la grammaire, contrainte des règles du roman (division en chapitres, etc.) ou de la tragédie classique (règle des trois unités), contrainte de la versification générale, contraintes des formes fixes (comme dans le cas du rondeau ou du sonnet), etc. (Le Lionnais, "La LiPo" 20)

Every literary work constructs itself around some inspiration (this is at least what its author lets us believe) which is to accommodate as much as possible a series of constraints which nest like Russian dolls. Constraints of vocabulary or grammar, constraints of the rules of the novel (division into chapters, etc.) or of classical tragedy (rule of the three unities), constraints of general versification, constraints of fixed forms (as in the case of the rondeau or of the sonnet), etc.

Le Lionnais also refers to literary disorder with the phrase "littérature-cri" ou "littérature-borborygme" (Le Lionnais "Le second Manifeste" 25), a form of selfgenerated and inarticulated writing that, Le Lionnais specifies, is, like inspiration, to be avoided-although inspiration is presented as merely fictitious and thus inoffensive (yet, he humorously adds, it may be practiced by OuLiPo members in their free time). In a comment on "The Philosophy of Composition" and the postscript of the novel La Disparition, Samuel B. Garren provides another example of the stigmatization, common to Poe and the OuLiPo, of uncontrolled motivations behind literature, here using Georges Perec as a witness:

This statement [about the "precision and rigid consequence of a mathematical problem" inherent in the composition of "The Raven"] would be music to Perec's ears, for with other members of the OuLiPo, he attacked the idea of literary inspiration, seeking to replace it with a variety of formal

${ }^{7}$ The substantive "constraint" comes from the Latin term constringere, to compress, which connotes this idea of control or mastery. 
constraints. La Disparition is cited as a premier achievement in this regard. In his "Postscript," Perec states, "I as an author hav[e] not an iota of inspiration (and, in addition, plac[e] no faith at all in inspiration as a Platonic form!" (381)

Thus, the OuLiPoe seems to reject the idea of unpremeditated processes of literary creation, since these processes involve a loss of agency. Concomitantly, the choice of constraint over all forms of spontaneity (and inspiration in particular) in writing also betrays the fear of a void. "La LiPo" notably opens with the following statement: "Ouvrons un dictionnaire aux mots: 'Littérature Potentielle'. Nous n'y trouvons rien. Fâcheuse lacune" (Le Lionnais 19; "Let us open a dictionary to the words 'Potential Literature.' We find nothing there. Regrettable lacuna"). Poe and the OuLiPo aim at defeating such lacunae by means of constraint, which (unlike inspiration) intrinsically provides the writer with the ability to catalyze not only the literary object, but also, potentially, authorial originality. (The OuLiPoe does strive for originality, as confirmed by a common évitement of plagiarism ${ }^{8}$ and by the will to interrupt or partially transgress existing, and persistent, literary conventions and productions: "la vérité est que la querelle des Anciens et des Modernes est permanente" [Le Lionnais, "La LiPo" 19; "the truth is that the quarrel of the Ancients and the Moderns is a permanent one].")

In 1994, this need for boosting the literary object and the author's creativity and originality in the face of a threatening void became the point of contact where Poe and the OuLiPo explicitly and officially met. In A Void, the English translation of La Disparition, Gilbert Adair, while preserving the lipogram in "e" on which Georges Perec's 1969 novel is constructed, introduces a number of changes in the source text, one of which involves Poe. In the narrative, which recounts the disappearance and subsequent search for "Anton Voyl" by his friends, six poems that constitute potential clues to his disparition are found. In Perec's novel, three of these poems are by Baudelaire. In the translation, Adair changes authors and replaces the French poet with none other than his American kindred spirit Edgar Allan Poe, whose works he had translated extensively. Adair does so while referring to Arthur Gordon Pym's "Black Bird" in his text, a bird that obviously points toward Poe's "The Raven." One can think of different motivations for this substitution. Samuel B. Garren mentions "Adair's thoughts about the nature of his English-language audience" (374), his will to remain, with this substitution, "in keeping with the spirit of Perec's novel," a spirit of "displacement" (375), and, of

${ }^{8}$ The OuLiPo substitutes the concept of "plagia[t] par anticipation"” (Le Lionnais "Le second Manifeste" 27) for plagiarism. This concept cannot be evoked without reference to Baudelaire, who defended his friend Manet, accused of pastiche, and, simultaneously himself, accused of plagiarizing Poe, by claiming that an artist can be influenced by another without knowing the latter's work. Baudelaire writes, in a letter to Armand Fraisse: "Et alors, je trouvai, croyez-moi, si vous voulez, des poèmes et des nouvelles dont j'avais eu la pensée, mais vague et confuse, mal ordonnée, et que Poe avait su combiner et mener à la perfection" (Correspondance 1:676; "And then I found, believe me if you will, poems and short stories the thought of which had occurred to me, yet only in a vague, confused, disordered form, and which Poe had known how to combine and lead to perfection"). And also: "La première fois que j'ai ouvert un livre de lui [Poe], j'ai vu, avec épouvante et ravissement, non seulement des sujets rêvés par moi, mais des PHRASES pensées par moi, et écrites par lui" (2:386; "The first time that I opened a book by him, I saw, with awe and ravishment, not only topics I myself had dreamt, but SENTENCES thought by me, and written by him"). For this reason (the subversion via—chronological—reversal of the concept of plagiarism), but also for another that I will soon be examining, the French author is a significant intermediary of the Poe/OuLiPo connection. 
course, Poe's "canonical status" (376), which mirrors Baudelaire's. But to my mind, Adair's substitution also clearly serves to signal the claim for authorial reason, control, and craftsmanship that is at stake in La Disparition and in all Oulipian compositions. Indeed, the mention and fame of "The Raven," with which Adair plays, cannot be disconnected from Poe's attempt in "The Philosophy of Composition" to theorize the composition of the poem through an exaggerated exhibition of rationalism that Baudelaire-well-aware of his kindred spirit's "affectation à cacher la spontanéité, à simuler le sang-froid et la délibération" (Oeuvres complètes II, "Notes nouvelles sur Edgar Poe" 335; "affectation to hide spontaneity, to simulate sang-froid and deliberation")—did not fail to notice when translating Poe's essay.

In view of the deep concern with literary disorder and a creative void (relative to textual production and/or to its newness) shared by Poe and the OuLiPo, and exemplified by Adair's translation of La Disparition, the concept of performance, which I argued is the modus operandi connecting these writers' designs, needs qualifying. It is indeed not so much performance as its oppositional complement contre-performance that informs "The Philosophy of Composition" and the two Oulipian manifestos. A struggle against contre-performance-in French, an abnormally unproductive or mediocre performance-is what ultimately motivates the texts I am examining.

For our writers, one of the paroxysmic manifestations and risks of contre-performance is, of course, the Death of the Author, to appropriate the title of Roland Barthes's famous essay. If for Poe Romantic inspiration is a form of authorial death in that it turns the writer into some sort of passive vessel, for Le Lionnais, writing in the 1960 s and 1970s, there is another school of thought that also annihilates authorship and that "plusieurs d'entre [les Oulipiens] considèrent avec circonspection" (Le Lionnais, "Le Second Manifeste" 23), a school of thought that claimed that "no single author originates a text which, instead, is conceived to be a cultural product consisting of many parts" (Garren 376). Both Poe and the OuLiPo fiercely resist this idea that the text may liberate itself from an identifiable géniteur. With them, the emancipation of the literary object is clearly feigned and instead reveals the necessary, vital presence of the mind that generates it, or its constraint. Hence the telling phrase "dérapage contrôlé" ["controlled skid"] (37) used by Burgelin to describe the Oulipian use of language. Indeed,

L'oulipien aime à faire croire qu'il ne songe qu'à disparaître: la structure, la machine qu'il a mise en marche fonctionne indépendamment de lui et décline sans broncher ses paradigmes. (Burgelin 37; my emphasis)

The oulipien likes to make one believe that he contemplates nothing but disappearing: the structure, the machine he has started functions independently from him and provides, without grumbling, its [variety of] paradigms.

Likewise, Poe's text is all about control. As Eliza Richards notes, the author's "gesture towards dominating the terrain of poetry with an alien rhetorical force ... becomes Poe's attempt to extend his poetic claim by expanding his performance of emotional distance via the poetic feature of the voice" (52).

To remedy more effectively the potential disappearance of the author, Poe and the OuLiPo also resort to mises en scènes that perform his existence. The OuLiPo's 
theatricality is quite concrete: the group held monthly meetings during which its members read or performed their latest work in front of their peers; more recently, this select audience has been enlarged as the OuLiPo makes itself increasingly available to the public by participating in various literary or pedagogical manifestations where the audience gets to see the authors and understand their work process. At the textual level, both Poe and the OuLiPo enforce performance by using direct discourse, whether through déclamation or startling apostrophes ("est-ce que vous vous imaginez que cela ait passé sans protestations?" [Le Lionnais, "La LiPo" 19; "do you think that this happened without complaints?"]) in writings that presuppose a dialogic mode and, as I mentioned earlier, the acute awareness of an addressee. To further theatricalize their discourses, Poe and Le Lionnais also skillfully have the reader visualize their words. For Poe, this seduction via images in motion consists in enabling us to imagine the huis-clos of the writer's mind in its utmost secrecy. When mentioning at what moment he "first put pen to paper," for instance, he lets us envision the always intriguing scene of (canonical) writing in the making, "the wheels and pinions-the tackle for scene-shifting - the step-ladders and demon-traps-the cock's feathers, the red paint and the black patches which ... constitute the properties of the literary histrio" (Poe 14). This theatrical convocation of the author and of what could be termed readerly voyeurism is enhanced by the vivid plots that Poe and the OuLiPo offer. For Poe, who "[1]ike a showman, ... opens the curtains on the theatricality of the lyric" and even "naturalizes theatricality as the poet's natural environment" (Richards 53), the peripetiae of "The Raven"'s composition are tragic in that they reveal the fatum inherent in its process of creation; conversely, the dramatization at play in the Ouvroir is relentlessly comic, putting forward absurd or, as we have seen, fantastic stories where the demand for consistency and unified levels of signification is freely ignored. About the invention of an old "querelle" over language, Le Lionnais for instance asks: "de quoi n'accusa-t-on pas (sans langage) le langage à cette époque?" ("La LiPo" 19; "Of what was language not accused [without language] at that time?") before concluding that "Elle ... ne se terminera qu'avec l'humanité à moins que les Mutants qui lui succéderont n'en assurent la relève" (19-20; "It . . . will only end with mankind unless the Mutants that follow mankind keep it alive").

To summarize, the emergence of a décor, of a protagonist's voice, of motion and of exciting action(s) confers on "The Philosophy of Composition" and on the two Oulipian manifestos a performative quality. And what is enacted, above all, is the recreation of the author's character, ${ }^{9}$ which also potentially allows for the recreation of the texts themselves: one may for instance think of "The Philosophy of Composition" as offering a new life and a new reading to "The Raven." The theoretical writings of Poe and the OuLiPo thus become plays that revisit the myth and mystique of the author-while being necessarily written by authors. "Un AUTEUR oulipien, c'est quoi? C'est 'un rat qui construit lui-même le labyrinthe dont il se propose de sortir'" ("What is an Oulipian AUTHOR? It is 'a rat that itself constructs the labyrinth that it sets itself the task of getting out of'"). In

\footnotetext{
${ }^{9}$ Here, one may think of the famous oulipian quote: "the members of the Oulipo are characters in an unwritten novel by Raymond Queneau" (Brotchie 213).
} 
a self-centered and experimental vortex, the author, and, by etymological implication, his auctoritas, are for Poe and the OuLiPo the (self-made) subjects and objects of their writing. Compulsively revolving around self-representation and ambitious self-generation, "The Philosophy of Composition," "La LiPo," and "Le second Manifeste" can thus be said to perform a narcissistic authorial crisis.

Behind this (staging of a) crisis of the self arguably lie other interrogations that motivate Poesque and Oulipian performances. Behind the refusal of the death of the author, in other words, lies the negation of other deaths: that of the signifier-and thus, potentially, of the signified-as well as that of the human. Owing to their supplementary nature, ${ }^{10}$ Poe's and Le Lionnais's theoretical writings mark a surenchère of the word, of meaning, and of man's presence. This is confirmed by a number of Oulipian novels, such as La Disparition or Harry Mathews's 1987 book Cigarettes, and by the better part of Poe's works, since all are somehow structurally motivated by the loss of a loved one-a friend, for Perec's novel; a wife, for Mathews's. Moreover, this loss expresses itself at various textual levels:

Selon la formule de J.C. Lebensztejn, La Disparition 'est toute construite autour de ce vide: la lettre manquante,' notamment sur le plan matériel—ou grammatique-, mais aussi thématique et narratif. Ainsi, l'omission du E se voit remplacée par un réseau d'obsessions sémantiques. Les figures du néant et l'idée de mort seront par exemple les substituts représentatifs de cette expulsion. (Sirvent 13)

According to J.C. Lebensztejn's formula, La Disparition 'is entirely constructed around this void: the missing letter, notably at a material—or grammatic_level, but also at the thematic and narrative levels. Thus, the omission of the $\mathrm{E}$ finds itself replaced with a network of semantic obsessions. The figures of nothingness and the idea of death will be, for instance, the representative substitutes of this expulsion.

Michel Sirvent also analyzes the chromatism at stake in Perec's novel as a system of graphic mourning and erasure:

"Ainsi naquit, mot à mot, noir sur blanc, surgissant d'un canon d'autant plus ardu qu'il apparaît d'abord insignifiant pour qui lit sans savoir la solution, un roman .... [ . . . Une écriture noire, aux accents mortifères pour signifier la blancheur, non plus la surface qui supporte l'écrit, mais ce que trace l'élimination d'un élément grammatique difficilement contournable. (14)

"Thus was born, word by word, black on white, arising from a canon [that is] all the more arduous as it first appears to be insignificant for whoever reads without knowing the solution, a novel ..." [ . . ] A black writing [style], with deadly overtones to signify whiteness, no longer the surface that bears the writing, but what the elimination of a grammatic element that is difficult to bypass traces.

Poe's narratives and verse-not to mention Poe's life itself-are similarly saturated with this idée de mort, as many critics have shown (see, for example, Bonaparte, Kennedy, and Bronfen). The idea at times even morphs into a true obsession: following the principle/(in)famous quote according to which "the death ... of a beautiful heroine is unquestionably the most poetical topic in the world," for example, Poe recurringly submits his female protagonists to sublimation, petrification, fragmentation, and other types of murderous objectification. ${ }^{11}$

Thus, a hyper-consciousness regarding mortality informs the works of Poe and

${ }^{10}$ These theoretical texts are indeed designed to supplement or complete literary texts as they announce or gloss their creation. Eliza Richards, referring to previous criticism, notably remarks that "The Philosophy of Composition" "works as an extension of the poem it interprets" $(48,49)$.

${ }^{11}$ I discuss the textual manifestations as well as the transcendence of these forms of female annihilation in Poe's verse in "The Female Figure of Poe's Poetry: A Rehabilitation," Poe Studies/Dark Romanticism 38 (2005): 17-28. 
the OuLiPo beyond the fear of authorial disappearance or impotence. Bearing this in mind, one is led to reconsider "The Philosophy of Composition" and the two Oulipian manifestos as antidotes that attempt to balance the ubiquity of death by promoting the birth and pleasure of the word. Poe's description of the careful thought process that is dedicated to each word's selection and Le Lionnais's hearty call for generating meticulously defined constraints indeed subscribe to a common discourse advocating the reanimation and revalorization of words. And this delectation in linguistic and poetic life, this creative jouissance that reason and constraint are said to decuple, embodies the counterpoint to the necrology-of the author, of the signifier, of the character-that the Poesque and Oulipian theoretical texts conceal. Again, one finds performance, whether theatrical or musical, in this lively jouissance of the word: Poe and Le Lionnais for instance sometimes become comedians keen on puns and playful metaphors. Le Lionnais thus talks about "chefs d'oeuvres et . . . oeuvres moins chefs" ("La LiPo" 20; "masterpieces and ... pieces less masterful") and compares his initial remarks with a few "simples amuse-gueules destinés à faire patienter les affamés" (19; "simple appetizers destined to keep the starving waiting"), thereby making the pleasure of the word a literal, sensorial one. Or else, the writers suddenly seem to incarnate old-fashioned orators, as shown by Poe's repeated use of Latinisms and archaic terminology. (Le Lionnais also indulges in such phrases as "leur trop féaux imitateurs" ["La LiPo" 20; "their all-too devoted imitators"].)

While reasserting, via performance, the significance of the word, while submitting it to constraint in order to revitalize it, so to speak, Poe and the OuLiPo symbolically perform a devoir de mémoire where writing, in re-marking the word, re-marks as unforgettable not only the text, but also the beings that engender and/or gravitate around/within it. With "The Philosophy of Composition," Poe reinscribed his paternity on "The Raven" and made its success perennial ${ }^{12}$ —and perhaps, from a biographical perspective, simultaneously reiterated the memorial celebration of one of the many "Lenores" he himself had lost by 1846 (his mother, Elizabeth Arnold Poe, who died in 1811 at the age of 24; his alleged first platonic love and idealized mother figure, Jane Stith Stanard, who died in her thirties when he was fifteen years old; his adoptive mother, Frances Allan, who died a few years later, in 1829).$^{13}$ Le Lionnais, for his part, also knew all too well the reality of death. Although his life is not as well known as Georges Perec's,${ }^{14}$ he

12 "Published in Graham's Magazine in April 1846, the essay rode the wave of the poem's success. ... Poe hoped to create a second sensation" (Richards 53).

13 "The Philosophy of Composition" might also be seen as the celebration of the author's survival. Thus, Daniel Hoffman suggests that it functions as a strategy that gave Poe the capacity to overlook and express the grief that followed the loss of "beautiful wom[e]n," thereby allowing him to defeat insanity: "What is the relation between his claim that imagination is a rational and orderly premeditated process and his need to drape it in crepe at the bier of a beautiful woman? What is the connection but that the straightjacket method enables the poet to deal with his obsessive and inescapable subject by compelling him to think about something else, something other than the woe vibrating within him which to think of would overcome him. So the method of his art enables the madness of his matter to be spoken" (92).

${ }^{14}$ Perec's "father was killed in June 1940 while serving in the French army; his mother was deported in 1942 and died in Auschwitz. Perec spent the war with relatives who had taken refuge in the French Alps and lived with them during the remaining years of his childhood and adolescence" (Brotchie 205-06). 
too suffered from the horrors of World War II: "he was arrested for his Resistance work and imprisoned in the Dora concentration camp" (Brotchie 164). His manifestos, with their provocative and charming tone, also express a deep ambition and are the statement of a strong presence that resists disappearing or going unnoticed. This refusal-this denial, perhaps—of man's ephemerality is further crystallized in the fact that, although Le Lionnais did not have time to complete a third Oulipian manifesto before his death, this third manifesto still has, to this day, a place reserved for it in the "Bibliothèque Oulipienne" under "B.O. 30." An empty place, but an eternal one, which echoes the fact that all Oulipian members are not only lifelong members, but also post-mortem ones. Thus, Poe, the OuLiPo, and the writing of constraint have an ultimate performance in common: that of existence.

In "The Philosophy of Composition," "La LiPo (Le premier Manifeste)," and "Le second Manifeste" Poe and the OuLiPo share a common passion for the rationalist potential of constraint, but also a marked penchant for its subversion, which they reveal with ostentation. Their texts are in fact performances where, behind the hypertrophic affirmation of a controlled literary object, there looms a defense of the self and its need for recognition. Indeed, by insisting on putting the (rational, not the emotional) authorial self back at the center of the literary edifice, Poe and the OuLiPo seek to (re)assert the importance of the writer. This emphatic signature seems to unveil the anguish of a polymorphous disappearance: the disappearance of the writer's agency, synonymous with the potential erasure of the text and/or of its novelty; the disappearance of the letter, of the word, or of the characters at stake in their writing; but also that of human existence whose inclination toward death is continuously challenged by ubiquitous linguistic rejoicing and creation that perpetuate life and a fundamental vitality. In sum, the call for constraints expressed in "The Philosophy of Composition," "La LiPo," and the "Le second Manifeste" enables Poe and the OuLiPo to impose a presence, to orchestrate a staging of themselves, and, thereby, to prematurely and actively shape the memory of their productions. Theirs is a propitiatory staging, which aims at securing a benevolent, if not admiring, curiosity.

\section{Princeton University}

\section{Works Cited}

Addams, Charles. "Nevermore." Cartoon. New Yorker. 29 Oct. 1973: 33.

Baudelaire, Charles. Correspondance. Ed. Claude Pichois. Paris: Gallimard, 1973. 2 vols. . CEurres complètes. Ed. Claude Pichois. Paris: Gallimard, 1975. 2 vols.

Benabou, Marcel, and Jacques Roubaud. "OULIPO? Qu'est ceci ?" Ecole Centrale de Lille. <http:// www2.ec-lille.fr/ book/oulipo/info/presentation.shtml>.

Bonaparte, Marie. The Life and Works of Edgar Allan Poe: A Psycho-Analytic Interpretation. Trans. John Rodker. London: Imago, 1949.

Bronfen, Elizabeth. Over Her Dead Body: Death, Femininity and the Aesthetic. New York: Routledge, 1992. 
COMPARATIVE LITERATURE / 124

Brotchie, Alastair, and Harry Mathews, eds. Oulipo Compendium. London: Atlas Press, 1998.

Burgelin, Claude. "Esthétique et éthique de l'Oulipo." Magazine Littéraire 398 (May 2001): 36-39.

Burke, Kenneth. Language as Symbolic Action; Essays on Life, Literature, and Method. Berkeley: University of California Press, 1966.

Garren, Samuel B. "The 'Too Long Unjoin'd Chain': Gilbert Adair's Use of Edgar Allan Poe in His Translation of Georges Perec's La Disparition.” CLA Journal 44 (March 2001): 373-82.

Hoffman, Daniel. Poe Poe Poe Poe Poe Poe Poe. Garden City: Doubleday, 1972.

Jannacone, Pasquale. "The Aesthetics of Edgar Poe." Poe Studies/Dark Romanticism 7 (1974): 1-13.

Kennedy, J. Gerald. Poe, Death, and the Life of Writing. New Haven: Yale University Press, 1987.

Le Lionnais, François. "La LiPo (Le premier Manifeste)." Oulipo, La littérature potentielle (Créations Re-créations Récréations). Paris: Gallimard, 1973. 19-22.

"Le second Manifeste." Oulipo, La littérature potentielle (Créations Re-créations Récréations). Paris: Gallimard, 1973. 23-27.

Mathews, Harry. Cigarettes. New York: Weidenfeld \& Nicolson, 1987.

Poe, Edgar Allan. "The Philosophy of Composition." Edgar Allan Poe: Essays and Reviews. Ed. G.R. Thompson. New York: Library of America, 1984. 13-25.

"The Poetic Principle." Edgar Allan Poe: Essays and Reviews. Ed. G.R. Thompson. New York: Library of America, 1984. 71-94.

Richards, Eliza. Gender and the Poetics of Reception in Poe's Circle. Cambridge: Cambridge University Press, 2004.

Sirvent, Michel. "Lettres volées (métareprésentation et lipogramme chez E.A. Poe et G. Perec)." Littérature 83 (October 1991): 12-30. 